\title{
(5)
}

\author{
AL-DZIKRA \\ Jurnal Studi Ilmu Al-Qur'an Dan Al-Hadits \\ http://ejournal.radenintan.ac.id/index.php/al-dzikra \\ Volume 12, No. 2, Desember Tahun 2018, Halaman 231 - 256 \\ DOI://dx.doi.org/10.24042/al-dzikra.v12i2.3897
}

\section{TREND STUDI AL-QUR'AN DI LINGKUNGAN MASYARAKAT KOTA BANDAR LAMPUNG}

\author{
Siti Badi'ah \\ UIN Raden Intan Lampung \\ Sitibadiahjuanda638@gmail.com
}

\section{Abastrak}

Studi al-Qur'an merupakan bagian dari studi Islam. Dalam studi al-Qur'an ini menempatkan al-Qur'an sebagai sasaran kajian. Semua hal yang berkaitan dengan al-Qur'an dikaji dan diteliti sehingga menghasilkan atau menemukan sesuatu yang diharapkan dari kajiannya, baik dari sisi internalnya maupun eksternalnya. Pertanyaan yang muncul, apakah perkembangan studi Qur'an tersebut telah menyentuh 'posisi' Qur'an di tengah dinamika realitas kontemporer masyarakat Islam di Indonesia? Bagaimana studi Qur'an seharusnya menjawab realitas kontemporer di Indonesia khususnya di Kota Bandar Lampung? Sebagai kota terbesar dan terpadat ketiga di Pulau Sumatera setelah Medan dan Palembang menurut jumlah penduduk, sehingga mengkaji tentang trend studi Qur'an di lingkungan masyarakat Kota Bandar Lampung menjadi sangat menarik. Penelitian yang bersifat deskriptif analisis teknik pengambilan sampel dalam penelitian ini menggunakan cluster sampling (Area Sampling) juga cluster random sampling, yang menjadikan majlis taklim yang berada di kecamatan Sukarame Kota Bandar Lampung sebagai sampelnya. Sehingga diketahui bahwa trend studi Qur'an di lingkungan masyarakat Kota Bandar Lampung lebih mengarah kepada kajian living Qur'an dan tafsir, dengan 
digital qur'anic studies sebagai pola kajian baru dalam diskursus studi al-Qur'an dan tafsirnya.

Kata Kunci: Trend, Studi Al- Qur'an, Masyarakat, Bandar Lampung.

\section{A. Pendahuluan}

Perkembangan Islamic Studies di Indonesia sulit dilepaskan dari laju positif studi Qur'an kontemporer baik yang dilakukan di Perguruan Tinggi Agama Islam (PTAI) maupun komunitas-komunitas penggiat studi Islam di tanah air. PTAI, melalui jurusan Tafsir Hadis atau Studi Qur'an, telah banyak memproduksi temuan menarik baik pada tingkat skripsi, tesis atau disertasi. Tidak jarang temuan penelitian tersebut dipublikasikan dan menjadi rujukan perkuliahan studi Qur'an; dua di antaranya adalah Khazanah Tafsir Indonesia: Dari Hermeneutika hingga Ideologi dan Epistemologi Tafsir Kontemporer. ${ }^{1}$ Di lain sisi, melalui pendekatan kritis, para komunitas penggiat studi Islam juga tak mau ketinggalan dalam mereproduksi pemikiranpemikiran baru tentang studi Qur'an. Satu publikasi yang patut disebut adalah Metodologi Studi Qur'an ${ }^{2}$ yang menyajikan pendekatan kritis dalam memahami kalam Ilahi. Dengan temuantemuan penelitian tersebut, studi Qur'an menjadi salah satu kajian yang banyak diminati baik oleh kalangan akademisi di perguruan tinggi maupun cendekiawan secara umum.

Pertanyaan lain yang muncul, apakah perkembangan studi Qur'an tersebut telah menyentuh 'posisi' Qur'an di tengah dinamika realitas kontemporer masyarakat Islam di Indonesia? Sepakat atau tidak, muslim di Indonesia sedang berada di muara jerat kapitalisme dan produk-produk konsumerisme global. Diskursus Islam kemudian sulit dilepaskan dari tuntutan pasar; dengan kata lain masyarakat Islam dituntut untuk beradaptasi dengan pasar. Bagaimana studi Qur'an seharusnya menjawab realitas kontemporer yang lahir di Indonesia, seperti pengajaran tafsir di televisi atau model iqra', hafalan Qur'an atau pelurusan LKiS, 2010).

1 Abdul Mustaqim, Epistemologi Tafsir Kontemporer (Yogyakarta:

2 Abd Moqsith Ghazali (ed.), Metodologi Studi al-Qur'an (Jakarta: Gramedia, 2010). 
tajwid by phone di radio, layanan sms ayat, kemunculan mushaf khusus untuk perempuan atau mushaf braille, musabaqah tilawatil Qur'an atau puitisasi dan politisasi ayat, atau kaligrafi ayat yang begitu indah penuh simbol. Berawal dari sebuah argumen bahwa studi Qur'an seharusnya memposisikan manusia sebagai penafsir, bukan Qur'an, sebagai subjek studi Qur'an, tulisan ini berupaya memaparkan alternatif tren studi Qur'an di Indonesia khususnya di Bandar Lampung. Sebagai kota terbesar dan terpadat ketiga di Pulau Sumatera setelah Medan dan Palembang menurut jumlah penduduk, mengkaji tentang trend studi Qur'an di lingkungan masyarakat Kota Bandar Lampung menjadi sangat menarik.

Penelitian ini akan menggunakan metode pendekatan kualitatif, yang bersifat deskriptif analisis dengan teknik pengambilan sampel dalam bentuk cluster sampling (Area Sampling) juga cluster random sampling, yang menjadikan majlis taklim yang berada di kecamatan Sukarame Kota Bandar Lampung sebagai sampelnya. Dengan begitu akan diketahui trend studi al-Qur'an dan alternatif tren studi Qur'an yang bisa dikembangkan lebih lanjut di lingkungan masyarakat Bandar Lampung. Sehingga, peneliti berharap melalui pemaparan alternatif tren ini, penelitian-penelitian baru tentang tren tertentu yang ditawarkan di sini dapat segera lahir, sehingga studi Qur'an di Indonesia tidak hanya terkesan text-oriented, tetapi juga sanggup mengkaji Qur' an in society.

\section{B. Kebutuhan dan Perkembangan Studi Al-Qur'an}

Sebagaimana yang telah diketahui bahwa kehidupan manusia di dunia pasti dipenuhi dengan permasalahan. Dari masa ke masa, permasalahan selalu berkembang menyesuaikan dengan tempat dan waktunya, hubungannya dengan yang lain, dan seterusnya. Kalau masa al-Qur'an diturunkan belum dikenal permasalahan yang berkaitan dengan term-term Hak Asasi Manusia (HAM), gender, ekologi dan lingkungan, muslim diaspora, eksklusivisme, dan pluralisme, dan lain-lain yang justru sekarang ini menjadi permasalahan yang secara intens didiskusikan.

Keberadaan al-Qur'an sangat dibutuhkan manusia dalam menghadapi permasalahan-permasalahan tersebut. Berkaitan dengan penghadapan masalah sebagaimana di atas, oleh Abuddin 
Nata, bahwa al-Qur'an dipetakan menjadi 3 (tiga) fungsi, yaitu Pertama, al-Qur'an berfungsi sebagai konfirmasi, artinya alQur'an berfungsi untuk memperkuat pendapat-pendapat akal pikiran atas pemecahan masalah tertentu dan menginformasikan terhadap hal-hal yang tidak dapat dicapai oleh akal. Kedua, alQur'an sebagai justifikasi, yaitu sebagai hakim yang menentukan jalan kehidupan manusia agar berjalan lurus. Itulah sebabnya ketika manusia berselisih dalam segala urusannya, untuk memecahkannya hendaknya berhakim pada al-Qur'an. Ketiga, alQur' an sebagai kendali maka dia memerankan fungsinya sebagai pengontrol dan korektor terhadap perjalanan hidup manusia di masa lalu. ${ }^{3}$

Mengingat pentingnya posisi al-Qur'an bagi kehidupan manusia, maka kajian tentang al-Qur'an adalah bentuk respons atas penerimaan al-Qur'an sebagai realitas yang tak bisa dipungkiri adanya. Kajian tentang al-Qur'an ini telah ada sejak alQur'an ini ada. Perhatian tidak hanya diberikan oleh Nabi Muhammad dan umatnya saja, tetapi orang-orang kafir Quraisy juga menaruh perhatian terhadapnya. Berkaitan dengan perhatian yang diberikan oleh Nabi dan umatnya atas al-Qur'an, yang hasilnya seringkali dikenal dengan tafsir, di sepanjang sejarahnya diklasifikasikan atas 3 (tiga) tahapan berdasarkan karakteristik yang menonjol, yaitu tahap formatif, tahap afirmatif, dan tahap reformatif. ${ }^{4}$ Penjelasan masing-masing :

\section{Tahap Formatif.}

Tahap formatif dalam perkembangan studi al-Qur'an yakni berupa tafsir-tafsir yang berbasis pada nalar mitis, artinya hasil penafsiran masih diterima begitu saja sebagai kebenaran tanpa kritik, tidak pernah ada seorangpun yang mempertanyakan produk penafsiran yang dihasilkan. Secara historis, tahapan ini terjadi di sepanjang Nabi Muhammad

\footnotetext{
1998), h.71

3 Abuddin Nata, Metodologi Studi Islam, (Jakarta : Rajawali Press,

4 Pentahapan di atas adalah menurut Abdul Mustaqim, lihat dalam Abdul Mustaqim, "Pergeseran Epistemologi Tafsir :dari Nalar Mitis-Ideologis Hingga Nalar Kritis", dalam Tashwirul Afkar, No.18 Tahun 2004, h. 89-109. Juga dalam Abdul Mustaqim, Pergeseran Epistemologi Tafsir, (Yogyakarta :Pustaka Pelajar, 2008). Penjelasan dan tulisan tentang hal ini juga diambil secara langsung dari sumber tersebut.
} 
SAW masih hidup. Begitu al-Qur'an diwahyukan, Nabi langsung menerima, memahami, menafsirkan, dan mengajarkannya kepada para sahabat. Model penafsirannya masih bersifat ijmali dan disampaikan secara oral melalui metode riwayat, sebab peradaban Arab saat itu masih berupa peradaban lisan dan periwayatan, bukan peradaban tulis dan penalaran. Nabi juga belum merumuskan metodologi penafsiran secara sistematis sebab kegiatan penafsiran saat itu lebih bersifat praktis implementatif.

Setelah Nabi wafat, tradisi penafsiran yang demikian berlanjut sampai masa para sahabat, seperti Abdullah Ibn Abbas, Abdullah Ibn Mas'ud, Zayd Ibn Tsabit, dan seterusnya. Model penafsirannya relatif sama dengan masa Nabi. Dan sumber penafsirannya adalah al-Qur'an. Setelah generasi sahabat, penafsiran semacam ini dilakukan oleh para tabiin. Paling tidak ada 3 (tiga) aliran yang menonjol di era ini, yaitu yang pertama aliran Makkah adalah mereka yang berguru pada Ibn Abbas; yang kedua aliran Madinah adalah mereka yang berguru kepada Ubay Ibn Ka'ab; yang ketiga aliran Irak adalah mereka yang berguru kepada Abdullah Ibn Mas'ud. Sementara itu ada yang menambahkan satu aliran lagi yaitu aliran Bashrah. Jika aliran Makkah dan Madinah cenderung bercorak riwayat, maka dari aliran Irak ini muncul benih-benih tafsir bi al-ra'yi, yang cenderung menggunakan akal dan penalaran atau ijtihad.

Pasca tabiin, penafsiran dilakukan oleh generasi atba al- tabiin. Pada masa ini pembukuan produk penafsiran dilakukan secara khusus, di antaranya adalah Kitab Tafsir Ma'ani al-Qur'an karya al-Farra adalah karya tafsir periode ini yang sampai ke kita sekarang ini.

\section{Tahap Afirmatif.}

Penafsiran pada tahap afirmatif ini banyak dipengaruhi oleh bias-bias ideologis, artinya penafsiran masa itu lebih didominasi oleh kepentingan-kepentingan tertentu sehingga al-Qur'an seringkali diperlakukan untuk melegitimasi kepentingan tententu. Posisi al-Qur'an benar-benar sebagai obyek yang subyeknya adalah penafsir. Di era ini berbagai kitab tafsir dengan berbagai kecenderungan dan kepentingan 
tertentu bermunculan sehingga nantinya muncul beragam corak tafsir, seperti :

a. Tafsir bi al-Ma'tsur, Tafsir Jami' al-Bayan an Ta'wil alaiy Qur'an' karya al-Tabari,

b. Tafsir-tafsir bi al-Ra'yi, seperti : yang berorientasi hukum, Tafsir al-Jami' li Ahkami al-Qur'an, karya al-Qurtubi; tafsir yang berorientasi sufi, Tafsir Ruh al-Ma'ani, karya al- Alusy; tafsir yang berorientasi falsafi, yaitu Tafsir Mafatih al-Ghaib, karya Imam al-Razi; tafsir yang berorientasi ilmi, yakni Jawahir fi Tafsir al-Qur'an, karya Tantawi Jauhari, tafsir yang mendukung paham Mu'tazilah, seperti Tafsir al-Kasysyaf, karya alZamakhsyari, tafsir yang mendukung paham teologi Syiah, di antaranya al-Tibyan fi Tafsir al- Qur'an, karya alThusi, dan lain-lain.

\section{Tahap Reformatif.}

Tafsir pada tahap ini ditandai dengan corak kritis dan transformatif. Corak kritis artinya produk penafsiran yang telah ada tidak diterima begitu saja sebagai 'kebenaran' tetapi mulai dikritisi dan dipertanyakan, sedangkan transformatif artinya tafsir dibangun untuk kepentingan transformasi umat dan untuk menjawab-memecahkan problem real yang sedang muncul dan berkembang di masyarakat.

Menurut Rotroud Wielandt, bahwa trend pokok dalam penafsiran di era ini adalah :

a. Menafsirkan al-Qur'an dari perspektif rasionalisme pencerahan,

b. Penafsiran saintifik terhadap al-Qur'an meski ini bukan yang pertama dilaksanakan,

c. Menafsirkan al-Qur'an dari perspektif kajian-kajian sastra,

d. Usaha-usaha untuk mengembangkan teori baru penafsiran yang memperhatikan historisitas al-Qur'an,

e. Penafsiran dalam mencari pendekatan baru terhadap alQur'an, 
f. Penafsiran al-Qur'an secara maudhui dalam implementasi praktiknya tak bisa dikesampingkan. ${ }^{5}$

Produk penafsiran di era ini sebagaimana dilaksanakan oleh tokoh-tokoh, seperti : Fazlurrahman, Nasr Hamid Abu Zayd, Aminah Wadud Muhsin, M. Arkoun, dan lain-lain.

\section{Kondisi Masyarakat Kota Bandar Lampung}

Kota Bandar Lampung adalah sebuah kota di Indonesia sekaligus ibukota dan kota terbesar di Provinsi Lampung. Bandar Lampung juga merupakan kota terbesar dan terpadat ketiga di Pulau Sumatera setelah Medan dan Palembang menurut jumlah penduduk, serta termasuk salah satu kota besar di Indonesia dan Kota terpadat di luar pulau Jawa. Kota Bandar Lampung merupakan Ibu Kota Propinsi Lampung. Kota Bandar Lampung terletak di wilayah yang strategis karena merupakan daerah transit kegiatan perekonomian antar pulau Sumatera dan pulau Jawa, sehingga menguntungkan bagi pertumbuhan dan pengembangan kota Bandar Lampung sebagai pusat perdagangan, industri dan pariwisata.

Sebelum tanggal 18 Maret 1964, Propinsi Lampung merupakan keresidenan. Berdasarkan Peraturan Pemerintah pengganti Undang-undang No. 3 tahun 1964, yang kemudian menjadi Undang-undang No. 14 tahun 1964, Keresidenan Lampung ditingkatkan menjadi Propinsi Lampung dengan Ibu Kota nya Tanjungkarang-Telukbetung. Selanjutnya berdasarkan Peraturan Pemerintah No. 24 Tahun 1983 (Lembaran Negara tahun 1983 Nomor 30, Tambahan Lembaran Negara Nomor 3254). Kotamadya Daerah Tingkat II TanjungkarangTelukbetung diganti namanya menjadi Kotamadya Daerah Tingkat II Bandar Lampung terhitung sejak tanggal 17 Juni 1983, dan sejak tahun 1999 berubah nama menjadi Kota Bandar Lampung. ${ }^{6}$

Secara geografis, Kota Bandar Lampung terletak pada 5020' sampai dengan 5030' lintang selatan dan 105028' sampai

5 Rotroud Wielandt, “Tafsir al-Qur'an: Masa Awal Modern dan Kontemporer', dalam Tashwirul Afkar, No.18 tahun 2004, h. 63-87

6 Bandar Lampung Dalam Angka 2010, Lampung; Badan Pusat Statistik Kota Bandar Lampung, 2010, hlm. Xliii. 
dengan 105037' bujur timur. Letak tersebut berada pada Teluk Lampung di ujung selatan pulau Sumatera. Berdasarkan kondisi ini, Kota Bandar Lampung menjadi pintu gerbang utama pulau Sumatera tepatnya kurang lebih $165 \mathrm{~km}$ sebelah barat laut Jakarta dan memiliki peran sangat penting selain dalam kedudukannya sebagai ibu kota Provinsi Lampung juga merupakan pusat pendidikan, kebudayaan dan perekonomian bagi masyarakat.

Kota Bandar Lampung memiliki luas wilayah 197,22 Km2 yang terdiri dari 13 kecamatan dan 98 kelurahan. Secara administratif Kota Bandar Lampung dibatasi oleh: ${ }^{8}$

Sebelah Utara berbatasan dengan kecamatan Natar kabupaten Lampung Selatan.

Sebelah Selatan berbatasan dengan Teluk Lampung.

- Sebelah Barat berbatasan dengan kecamatan Gedung Tataan dan Padang Cermin kabupaten Pesawaran.

Sebelah Timur berbatasan dengan kecamatan Tanjung Bintang kabupaten Lampung Selatan.

Secara demografis, kota Bandar Lampung terdiri dari banyak etnik, sehingga bisa dibilang kota Bandar Lampung bersifat heterogen, dengan jumlah penduduk sebagai berikut:

Jumlah Penduduk Kota Bandar Lampung dirinci menurut Kecamatan, Jenis Kelamin, dan Sex Ratio Tahun 2011-2015

\begin{tabular}{|l|c|c|c|c|}
\hline \multicolumn{1}{|c|}{ Kecamatan } & Laki-laki & Perempuan & Jumlah & $\begin{array}{c}\text { Sex } \\
\text { Ratio }\end{array}$ \\
\hline \multicolumn{1}{|c|}{$(1)$} & Male & Female & Total & $(2)$ \\
$(3)$ & $(4)$ & $(5)$ \\
\hline Teluk Betung Barat & 15363 & 14436 & 29799 & 106 \\
\hline $\begin{array}{l}\text { Teluk Betung Timur } \\
\text { Teluk Betung } \\
\text { Selatan }\end{array}$ & 21396 & 20249 & 41645 & 106 \\
\hline Bumi Waras & 28960 & 19393 & 39353 & 103 \\
\hline Panjang Karang & 37936 & 27793 & 56742 & 104 \\
\hline $\begin{array}{l}\text { Tanjung } \\
\text { Timur }\end{array}$ & 18520 & 18588 & 37108 & 100 \\
\hline Kedamaian & 26584 & 26008 & 52592 & 102 \\
\hline Teluk Betung Utara & 25300 & 25293 & 50593 & 100 \\
\hline
\end{tabular}

${ }^{7}$ Ibid., h. xli.

${ }^{8}$ Ibid. 


\begin{tabular}{|l|c|c|c|c|}
\hline $\begin{array}{l}\text { Tanjung Karang } \\
\text { Pusat }\end{array}$ & 25263 & 25863 & 51126 & 98 \\
\hline Kemiling & 32683 & 32954 & 65637 & 99 \\
\hline Langkapura & 17129 & 16815 & 33944 & 102 \\
\hline Kedaton & 24495 & 24560 & 49055 & 100 \\
\hline Rajabasa & 24472 & 23555 & 48027 & 104 \\
\hline Tanjung Senang & 22900 & 22875 & 45775 & 100 \\
\hline Labuhan Ratu & 22606 & 22237 & 44843 & 102 \\
\hline Sukarame & 28487 & 28434 & 56921 & 100 \\
\hline Sukabumi & 29348 & 27986 & 57334 & 105 \\
\hline Way Halim & 30612 & 30881 & 61493 & 99 \\
\hline 2015 & 493411 & 485876 & 979287 & 102 \\
\hline 2014 & 484215 & 476480 & 960695 & 102 \\
\hline 2013 & 475039 & 467000 & 942039 & 102 \\
\hline 2012 & 456620 & 446265 & 902885 & 102 \\
\hline 2011 & 450802 & 440572 & 891374 & 102 \\
\hline Sumber : & Badan Pusat Statistik Kota Bandar Lampung \\
\hline
\end{tabular}

Agama mayoritas yang dianut oleh sekitar 92,63\% masyarakat Kota Bandar Lampung adalah Islam. Selain itu, ada juga yang beragama Kristen $3.55 \%$, Katolik $1.59 \%$, Hindu $0.35 \%$, Buddha $1.48 \%$, dan Kong $\mathrm{Hu} \mathrm{Cu} 0.04 \%$ yang rata-rata dianut masyarakat keturunan Tionghoa dan pendatang. Mengingat banyaknya jumlah penduduk masyarakat Bandar Lampung yang beragama Islam, maka tidak mengherankan jika terdapat banyak tempat Ibadah di daerah Bandar Lampung. Berikut adalah datadat anya:

Data Tempat Ibadah di Kota Bandar Lampung

\begin{tabular}{|l|c|c|}
\hline \multicolumn{1}{|c|}{ Kecamatan } & Masjid & Musholla \\
\hline \multicolumn{1}{|c|}{$(1)$} & $(2)$ & $(3)$ \\
\hline Teluk Betung Barat & 25 & 46 \\
\hline Teluk Betung Timur & 20 & 41 \\
\hline Teluk Betung Selatan & 18 & 46 \\
\hline Bumi Waras & 20 & 59 \\
\hline Panjang & 34 & 74 \\
\hline Tanjung Karang Timur & 16 & 32 \\
\hline
\end{tabular}




\begin{tabular}{|l|c|c|}
\hline Kedamaian & 32 & 39 \\
\hline Teluk Betung Utara & 22 & 49 \\
\hline Tanjung Karang Pusat & 28 & 46 \\
\hline Enggal & 19 & 23 \\
\hline Tanjung Karang Barat & 43 & 56 \\
\hline Kemiling & 83 & 32 \\
\hline Langkapura & 28 & 25 \\
\hline Kedaton & 35 & 33 \\
\hline Rajabasa & 50 & 25 \\
\hline Tanjung Senang & 46 & 29 \\
\hline Labuhan Ratu & 50 & 24 \\
\hline Sukarame & 44 & 26 \\
\hline Sukabumi & 62 & 72 \\
\hline Way Halim & 37 & 40 \\
\hline JUMLAH & 712 & 817 \\
\hline
\end{tabular}

Sedangkan untuk Data Masjid di Kota Bandar Lampung tahun 2018 adalah sebagai berikut:

\begin{tabular}{|c|l|l|l|l|}
\hline NO & KECAMATAN & \multicolumn{1}{|c|}{$\begin{array}{c}\text { NAMA } \\
\text { MASJID }\end{array}$} & \multicolumn{1}{|c|}{ TIPOLOGI } & ALAMAT \\
\hline 1 & Sukarame & $\begin{array}{l}\text { Masjid AL- } \\
\text { AMIN }\end{array}$ & $\begin{array}{l}\text { Masjid di } \\
\text { Tempat Publik }\end{array}$ & $\begin{array}{l}\text { Perumdam } \\
111 \\
\text { Sukarame } \\
\text { Bandar } \\
\text { Lampung }\end{array}$ \\
\hline 2 & Sukarame & $\begin{array}{l}\text { Masjid AL- } \\
\text { MUKMIN }\end{array}$ & $\begin{array}{l}\text { Masjid di } \\
\text { Tempat Publik }\end{array}$ & $\begin{array}{l}\text { JL. Sangiang } \\
\text { Lk. } \\
\text { Sukarame }\end{array}$ \\
\hline 3 & Sukarame & $\begin{array}{l}\text { Masjid AR- } \\
\text { RIDHO di }\end{array}$ & $\begin{array}{l}\text { Masjid } \\
\text { Terum Griya } \\
\text { Sukarame } \\
\text { Bandar } \\
\text { Lampung }\end{array}$ \\
\hline 4 & $\begin{array}{l}\text { Tanjungkarang } \\
\text { Timur }\end{array}$ & $\begin{array}{l}\text { Masjid } \\
\text { JAMI'ATUL } \\
\text { FITYAN }\end{array}$ & $\begin{array}{l}\text { Masjid didik } \\
\text { Tempat Publik }\end{array}$ & $\begin{array}{l}\text { JL.Merbabu } \\
\text { Kelurahan } \\
\text { Tanjung } \\
\text { raya }\end{array}$ \\
\hline 5 & Telukbetung & Masjid & Masjid Jami & Jl. \\
\hline
\end{tabular}




\begin{tabular}{|c|c|c|c|c|}
\hline & Barat & ISTIQOMAH & & $\begin{array}{l}\text { Laksamana } \\
\text { RE } \\
\text { Martadinata/ } \\
\text { Jl. Ikan } \\
\text { Sepat Gg } \\
\text { Kelapa, } \\
\text { Teluk } \\
\end{array}$ \\
\hline 6 & Kedaton & $\begin{array}{l}\text { Masjid Al- } \\
\text { Muhtadin }\end{array}$ & Masjid Jami & $\begin{array}{l}\text { Jl. } \\
\text { Parman Gg. } \\
\text { Sumur } \\
\text { Kelurahan } \\
\text { Pelita } \\
\text { Bandar } \\
\text { Lampung }\end{array}$ \\
\hline 7 & $\begin{array}{l}\text { Telukbetung } \\
\text { Selatan }\end{array}$ & $\begin{array}{l}\text { Masjid } \\
\text { DAARUN } \\
\text { NASHIHIN }\end{array}$ & $\begin{array}{l}\text { Masjid di } \\
\text { Tempat Publik }\end{array}$ & $\begin{array}{l}\text { GG. Randu } \\
\text { Daniel } \\
\text { Pancur Mas }\end{array}$ \\
\hline 8 & $\begin{array}{l}\text { Telukbetung } \\
\text { Selatan }\end{array}$ & $\begin{array}{l}\text { Masjid Ash- } \\
\text { shobirin }\end{array}$ & $\begin{array}{l}\text { Masjid di } \\
\text { Tempat Publik }\end{array}$ & $\begin{array}{l}\text { Jl.Hasanudin } \\
\text { Gg.Lampun } \\
\text { g Gunung } \\
\text { Mas }\end{array}$ \\
\hline 9 & Kemiling & $\begin{array}{l}\text { Masjid Iklas } \\
\text { Al-Azhar }\end{array}$ & Masjid Jami & $\begin{array}{l}\text { Bukit } \\
\text { Kemiling } \\
\text { Permai } \\
\end{array}$ \\
\hline 10 & Kemiling & $\begin{array}{l}\text { Masjid } \quad \text { Al- } \\
\text { Falaah }\end{array}$ & $\begin{array}{l}\text { Masjid di } \\
\text { Tempat Publik }\end{array}$ & $\begin{array}{l}\text { Kemiling } \\
\text { Raya Kodya } \\
\text { Bandar } \\
\text { Lampung } \\
\end{array}$ \\
\hline 11 & Rajabasa & $\begin{array}{l}\text { Masjid Ainul } \\
\text { Yaqin }\end{array}$ & $\begin{array}{l}\text { Masjid di } \\
\text { Tempat Publik }\end{array}$ & $\begin{array}{l}\text { Jl.Haji } \\
\text { Kamarudin } \\
\text { Kp. Madiun } \\
\text { Kecamatan } \\
\text { Rajabasah } \\
\text { Kadya }\end{array}$ \\
\hline 12 & Sukabumi & $\begin{array}{l}\text { Masjid Ainul } \\
\text { Yaqin }\end{array}$ & $\begin{array}{l}\text { Masjid di } \\
\text { Tempat Publik }\end{array}$ & $\begin{array}{l}\text { Raja Basah } \\
\text { Kodya } \\
\text { Bandar } \\
\text { Lampung }\end{array}$ \\
\hline
\end{tabular}




\begin{tabular}{|c|c|c|c|c|}
\hline 13 & $\begin{array}{l}\text { Telukbetung } \\
\text { Selatan }\end{array}$ & $\begin{array}{l}\text { Masjid } \\
\text { TRORIQUS } \\
\text { SYUHADA }\end{array}$ & Masjid Jami & $\begin{array}{l}\text { Laksamana } \\
\text { Mardinata } \\
\text { Pesawaran }\end{array}$ \\
\hline 14 & Sukabumi & $\begin{array}{l}\text { Masjid } \\
\text { Baiturrohman }\end{array}$ & Masjid Jami & $\begin{array}{l}\text { Sukabumi } \\
\text { Bandar } \\
\text { lampung }\end{array}$ \\
\hline 15 & Tanjung Senang & $\begin{array}{l}\text { Masjid Al- } \\
\text { Falah }\end{array}$ & Masjid Jami & $\begin{array}{l}\text { Perumas } \\
\text { Way Kandis } \\
\text { kecamatan } \\
\text { Tanjung } \\
\text { Senang } \\
\text { Kodya } \\
\text { Bandar }\end{array}$ \\
\hline 16 & Tanjung Senang & $\begin{array}{l}\text { Masjid Al- } \\
\text { Amin }\end{array}$ & $\begin{array}{l}\text { Masjid di } \\
\text { Tempat Publik }\end{array}$ & $\begin{array}{l}\text { Jl.Cendana } \\
\text { No.26 Lk.II } \\
\text { Tanjung } \\
\text { Senang } \\
\text { Bandar } \\
\text { Lampung }\end{array}$ \\
\hline 17 & Sukabumi & $\begin{array}{l}\text { Masjid } \\
\text { Baiturrohman }\end{array}$ & Masjid Jami & $\begin{array}{l}\text { Sukabumi } \\
\text { Bandar } \\
\text { Lampung }\end{array}$ \\
\hline 18 & $\begin{array}{l}\text { Tanjung karang } \\
\text { Barat }\end{array}$ & $\begin{array}{ll}\text { Masjid } & \text { Al- } \\
\text { Muhajirin } & \end{array}$ & Masjid Jami & $\begin{array}{l}\text { Perumahan } \\
\text { Taman Blora } \\
\text { Iman Bonjol } \\
\text { Gang Blora } \\
\text { RT.003 } \\
\text { Lk.II }\end{array}$ \\
\hline 19 & Sukabumi & $\begin{array}{l}\text { Masjid Al- } \\
\text { ikhwan }\end{array}$ & Masjid Jami & $\begin{array}{l}\text { Rt.02 Lk.01 } \\
\text { Kelurahan } \\
\text { Sukabumi } \\
\text { Kodya } \\
\text { Bandar } \\
\text { Lampung }\end{array}$ \\
\hline 20 & Rajabasa & $\begin{array}{l}\text { Masjid Nurul } \\
\text { Falah }\end{array}$ & Masjid Jami & $\begin{array}{l}\text { Rt.06 By } \\
\text { Pass raya } \\
\text { kelurahan } \\
\text { Rajabasa }\end{array}$ \\
\hline
\end{tabular}




\begin{tabular}{|l|l|l|l|l|}
\hline & & & $\begin{array}{l}\text { Raya kodya } \\
\text { Bandar }\end{array}$ \\
\hline
\end{tabular}

\section{Kondisi dan Rutinitas Jamaah Pengajian Kota Bandar Lampung}

Seperti yang telah disinggung di atas bahwa Islam menjadi agama mayoritas yang dipeluk oleh penduduk kota Bandar Lampung. Sebagai agama mayoritas, ajaran Islam pun tentunya sudah merasuk dikehidupan masyarakat Kota Bandar Lampung. Ajaran Islam ini sebenarnya dapat terlihat dari bagaimana mereka memahami dan memperlakukan al-Qur'an. Seperti yang telah kita ketahui bahwa al-Qur'an adalah salah satu kitab yang telah diturunkan oleh Allah kepada hamba-Nya yang termulia, Muhammad sebagai petunjuk untuk umat Islam. Untuk itu, tidaklah mengherankan jika keseharian masyarakat kota Bandar Lampung yang notabane nya beragama Islam selalu menjadikan al-Qur'an sebagai rutinitas sehari-hari.

Bahkan, untuk mengenal dan memahami al-Qur'an dengan baik, banyak warga yang telah memasukkan anak-anaknya ke Taman Pendidikan Al-Qur'an (TPA/TPQ) yang diselenggarakan di Masjid-masjid lingkungan tempat tinggal mereka. Ini terbukti dengan banyaknya Taman Pendidikan Al-Qur'an yang terdapat di Kota Bandar Lampung, TPA/TPQ Masjid al-Ikhwan Sukarame, TPA/TPQ Masjid Al-Huda Sukarame, TPA/TPQ Masjid An-Nur Sukarame, dan masih banyak lagi.

Tidak hanya itu saja, banyak juga masyarakat yang secara langsung mendatangkan guru les privat mengaji untuk anakanaknya ke rumah mereka masing-masing. Bahkan banyak juga lembaga-lembaga ataupun yayasan-yayasan yang secara khusus membuka kelas untuk program Tahsin, Talaqqi, Tahfiz, dan Bimbara. Semua itu bertujuan untuk memberikan layanan berupa pengetahuan dan keterampilan dalam menulis, membaca dan mengamalkan Al-Qur'an dalam kehidupan sehari-hari. Sehingga semua umat Islam khususnya di kota Bandar Lampung dapat membaca dan menulis al-Qur'an dengan baik dan benar sehingga terbentuklah generasi Qur'ani, yaitu generasi yang memiliki komitmen terhadap al-Qur'an sebagai sumber perilaku, pijakan hidup dan rujukan segala urusannya. Hal ini ditandai dengan 
kecintaan yang mendalam terhadap al-Qur'an, mampu dan rajin membacanya, terus menerus mempelajari isi kandungannya, dan memiliki kemauan yang kuat untuk mengamalkannya secara kaffah dalam kehidupan sehari-hari.

Karena itu, sangatlah wajar jika dijumpai banyak warga masyarakat kota Bandar Lampung yang selalu membiasakan diri dan keluarganya dengan mengaji atau membaca al-Qur'an setiap harinya. Artinya, mereka mempelajarai al-Qur'an hanya dengan membaca teksnya saja secara benar sesuai dengan tajwid dan mengikuti pengajian kajian al-Qur'an tentang cara membaca dan mengetahui terjemahnya. Sebab, sedari kecil mereka telah diajarkan untuk belajar membaca dan memahami al-Qur'an.

Aktifitas masyarakat Muslim di kota Bandar Lampung ternyata tidak hanya membaca teka Qur' an nya saja. Bagi jama'ah yang mempunyai pemahaman agama Islam yang lebih mumpuni, seperti mereka yang telah mengenyam pendidikan di Pondok Pesanteran ataupun kuliah di jurusan keagamaan, mereka akan mengkaji al-Qur'an tentang asbabun nuzul (latar belakang turunnya al-Qur'an) dan mempelajari tentang sejarah penulisan dan pengkodifikasian teks al-Qur'an. Ini semua dilakukan demi memperoleh pemahaman yang menyeluruh terhadap al-Qur'an.

Jika jama'ah yang mendalami dan mengkaji al-Qur'an tentang asbabun nuzul (latar belakang turunnya al-Qur'an) dan mempelajari tentang sejarah penulisan dan pengkodifikasian teks al-Qur'an sangat sedikit jumlahnya, lain halnya dengan jama'ah yang belajar dan memahami al-Qur'an dari segi tafsirnya. Sebab, dalam hal ini mereka mulai tertarik memahami teks al-Qur'an secara tematik untuk menjawab permasalahan yang ada dalam masyarakat. Ini terbukti dengan banyaknya jama'ah-jama'ah pengajian yang diadakan oleh masjid-masjid di sekitar kota Bandar Lampung.

\section{JADWAL KAJAN ISLAM ATAU TAKLIM UNTUK WILAYAH BANDAR LAMPUNG DAN SEKITARNYA.}

(Waktu Ba'da Maghrib s/d selesai)

\begin{tabular}{|c|c|c|}
\hline No & & Hari \\
\hline 1 & $\begin{array}{l}\text { Di Masjid Agung AL FURQON } \\
\text { Lungsir Bandar Lampung }\end{array}$ & $\begin{array}{l}\text { Hari Ahad malam } \\
\text { Senin }\end{array}$ \\
\hline & Di Masjid AL HIKMAH Jl. Pagar & Hari Senin ma \\
\hline
\end{tabular}




\begin{tabular}{|c|c|c|}
\hline & $\begin{array}{l}\text { Alam Gang PU Kedaton Bandar } \\
\text { Lampung. }\end{array}$ & $\begin{array}{l}\text { jama'ah pria dan } \\
\text { wanita). }\end{array}$ \\
\hline 3 & $\begin{array}{l}\text { Di Masjid AL HUDA Jl. Endro } \\
\text { Sukarame Bandar Lampung }\end{array}$ & $\begin{array}{ll}\text { Hari Selasa } & \text { malam } \\
\text { Rabu } & \text { (untuk } \\
\text { umum). } & \end{array}$ \\
\hline 4 & $\begin{array}{lrr}\text { Di Masjid AL } & \text { IMAN Jl. } & \text { Perintis } \\
\text { Kemerdekaan } & \text { Gang } & \text { Pusri } \\
\text { Tanjungkarang } & \text { Timur } & \text { Bandar } \\
\text { Lampung. } & & \\
\end{array}$ & $\begin{array}{lrr}\text { Hari Selasa } & \text { malam } \\
\text { Rabu dan } & \text { Hari } \\
\text { Kamis } & \text { Malam } \\
\text { Jum'at } & & \text { (untuk } \\
\text { umum) } & & \\
\end{array}$ \\
\hline 5 & $\begin{array}{l}\text { Di Masjid AL ANSHOR Jl. KH. } \\
\text { Hasyim Asy'ari Gedong Pakuwon } \\
\text { Teluk Betung Bandar Lampung. } \\
\end{array}$ & $\begin{array}{ll}\text { Hari Selasa } & \text { malam } \\
\text { Rabu } & \text { (untuk } \\
\text { umum). } & \\
\end{array}$ \\
\hline 6 & $\begin{array}{l}\text { Di Masjid AL KAUTSAR Jl. Kayu } \\
\text { Manis Sepang Jaya Way Halim } \\
\text { Bandar Lampung. }\end{array}$ & $\begin{array}{ll}\text { Hari Selasa } & \text { malam } \\
\text { Rabu } & \text { (untuk } \\
\text { umum). } & \\
\end{array}$ \\
\hline 7 & $\begin{array}{l}\text { Di Masjid AL IHSAN Jl. Pulau } \\
\text { Singkep Karangsari Sukarame Baru } \\
\text { BandarLampung. }\end{array}$ & $\begin{array}{ll}\text { Hari Rabu } & \text { malam } \\
\text { Kamis } & \text { (untuk } \\
\text { umum). } & \end{array}$ \\
\hline 8 & $\begin{array}{l}\text { Komplek } \\
\text { pung. }\end{array}$ & $\begin{array}{ll}\text { Hari Rabu } & \text { malam } \\
\text { Kamis } & \text { (untuk } \\
\text { umum). } & \\
\end{array}$ \\
\hline 9 & $\begin{array}{l}\text { Di Masjid AL FIRDAUS Jl. Urip } \\
\text { Sumoharjo Perumahan Bukit Kencana } \\
\text { Bandar Lampung }\end{array}$ & $\begin{array}{l}\text { Hari Kamis malam } \\
\text { Jum'at } \\
\text { umum). }\end{array}$ \\
\hline 10 & $\begin{array}{llr}\text { Di Masjid } & \text { JAMI' } & \text { BAITUL } \\
\text { MAKMUR Gang Catur Setelah Gang } \\
\text { Pasar Tani } & \text { Kemiling } & \text { Bandar } \\
\text { Lampung. } & & \\
\end{array}$ & $\begin{array}{ll}\text { Hari Jum'at malam } \\
\text { Sabtu } & \text { (untuk } \\
\text { umum). } & \end{array}$ \\
\hline 11 & $\begin{array}{l}\text { Di Masjid JAMI' AL ANSHOR } \\
\text { Perumahan Bukit Kemiling Permai } \\
\text { Bandar Lampung }\end{array}$ & $\begin{array}{ll}\text { Hari Sabtu malam } \\
\text { Ahad } & \text { (untuk } \\
\text { umum). } & \end{array}$ \\
\hline 12 & $\begin{array}{llr}\text { Di Masjid } & \text { BAITUSSALAM } \\
\text { Perumahan Taman Prashanti } 2 \\
\text { Sukarame Bandar }\end{array}$ & $\begin{array}{ll}\text { Hari Jum'at malam } \\
\text { Sabtu } & \text { (untuk } \\
\text { umum). } & \\
\end{array}$ \\
\hline
\end{tabular}




\begin{tabular}{|c|l|l|}
\hline 13 & $\begin{array}{l}\text { Di Masjid AL HANIF Sepang Jaya } \\
\text { Labuhan Ratu }\end{array}$ & Hari Ahad ke- 5 \\
\hline 14 & $\begin{array}{l}\text { Di Masjid AD DU'A Wayhalim } \\
\text { Bandar Lampung }\end{array}$ & $\begin{array}{l}\text { Setiap hari Ba'da } \\
\text { Magrib }\end{array}$ \\
\hline 15 & $\begin{array}{l}\text { Di Sekretariat AL ATSAR Jl. Pulau } \\
\text { Sebesi No. 38 Sukarame Bandar } \\
\text { Lampung, 35131. }\end{array}$ & $\begin{array}{l}\text { Hari Ahad malam } \\
\text { Senin dan hari } \\
\text { Jum'at malam } \\
\text { Sabtu (khusus } \\
\text { jama'ah pria). }\end{array}$ \\
\hline
\end{tabular}

Selain melaksanakan kajian atau pengajian rutin di masjidmasjid, masyarakat Muslim kota Bandar Lampung juga secara rutin mengadakan kegiatan-kegiatan keagamaan yang mencerminkan nilai-nilai Qur'ani seperti, tahlilan dan yasinan. Kegiatan keagamaan ini dinilai sebagai sebuah tradisi dari para ulama-ulama terdahulu yang harus terus dilestarikan. Kegiatan ini selain mengandung nilai religi, tent unya juga mengandung unsurunsur budaya di dalamnya. Unsur religinya tent unya terdapat pada bacaan-bacaan tahlil dan yasin yang di dalamnya memuat banyak sekali ayat-ayat al-Qur'an, juga berisi shalawat-shalwat kepada Nabi Muhammad saw. dan sebagainya yang telah diperintahkan dalam al-Qur'an. Sedangkan unsur-unsur budaya nya dapat dijumpai dari cara mereka mengadakan perkumpulan dari rumah ke rumah untuk melaksanakan kegiatan tersebut, lalu setelah pembacaan tahlil dan yasin usai, mereka pun akan disuguhi dengan berbagai aneka hidangan sebagai bentuk syukur dari pemilik rumah.

Kegiatan ini biasanya dilakukan oleh warga seminggu sekali di malam Jum'at. Ini karena malam Jum'at oleh mayoritas umat Islam dianggap sebagai malam mubarok, malam yang penuh berkah. Maka, tidaklah salah jika kegiatan yang penuh dengan nilai-nilai qur'ani tersebut dilaksanakan pada malam tersebut dengan harapan semua yang menjalankan mendapat berkahnya.

Tidak hanya itu, mereka juga selalu membiasakan membaca Surat ar-rahman dan Al-Waqiah pada setiap pagi setelah shalat subuh. Bahkan, ada juga beberapa jama'ah yang berusaha untuk menghafal satu ayat al-Qur'an dan maknanya pada setiap pertemuan yang diadakan pada majelis taklim yang 
mereka ikuti. Itu semua dilakukan sebagai bentuk kecintaan mereka terhadap al-Qur'an.

\section{E. Pemahaman Studi al-Qur'an Masyarakat Kota Bandar Lampung}

Setelah memaparkan berbagai kondisi dan rutinitas jamaah pengajian di kota Bandar Lampung di atas, kita kemudian dapat memetakan tentang arah pemahaman studi Qur'an yang terdapat dalam masyarakat Kota Bandar Lampung sebagai berikut:

\section{Dirasat Ma Fi al-Nas}

Yaitu sebuah pemahaman yang menjadikan teks atau ayat al-Qur'an sendiri sebagai obyek kajian. Tujuan kajian semacam ini bisa saja beragam, tergantung pada kepentingan dan keahlian masing-masing pengkaji. Sebagian pengkaji ingin menguak world view al-Qur'an tentang konsep permasalahan tertentu sehingga hasilnya dapat digunakan sebagai sarana legitimasi atau bahkan diaplikasikan dalam kehidupan sehari-hari. Praktek nyatanya adalah mereka yang mempelajarai al-Qur'an hanya dengan membaca teks nya saja secara benar sesuai dengan tajwid dan mengikuti pengajian kajian al-Qur'an tentang cara membaca dan mengetahui terjemahnya.

\section{Dirasah ma Haula al-Qur'an}

Untuk hal ini kita dituntut menempatkan hal-hal di luar teks al-Qur'an, namun masih berkaitan sangat erat dengan kemunculannya sebagai obyek kajian, seperti contoh kajian tentang asbab al-nuzul, sejarah penulisan dan kodifikasi teks, qira'ah, naskh mansukh, dan lain-lain. Praktek nyatanya adalah mereka yang mengikuti kajian al-Qur'an tentang asbabun nuzul (latar belakang turunnya al-Qur'an) dan mempelajari tentang sejarah penulisan dan pengkodifikasian teks al-Qur'an.

\section{Kajian Tafsir}

Pada bagian ini, masyarakat tidak hanya menjadikan teks sebagai sebuah bacaan tetapi juga berusaha untuk memahami teks al-Qur'an itu sendiri. Sebagaimana telah kita ketahui bahwa sejak al-Qur'an diturunkan pada masa Nabi hingga sekarang, al-Qur'an dipahami dan ditafsirkan oleh umat Islam, baik secara keseluruhan maupun hanya bagian-bagian tertentu, dan baik secara mushafi maupun secara tematik. Mereka ini adalah para jamaah yang 
belajar dan memahami al-Qur'an dari segi tafsirnya secara tematik untuk mendapatkan pemahaman yang lebih mendalam terhadap al-Qur'an sehingga mampu menjawab permasalahan yang ada dalam masyarakat.

\section{Living al-Qur'an dan Living Tafsir}

Yaitu pemahaman masyarakat tentang bagaimana mereka merespon terhadap teks al-Qur'an dan hasil penafsiran seseorang. Termasuk dalam pengertian masyarakat adalah resepsi mereka terhadap teks tertentu dan hasil penafsiran tertentu. Resepsi sosial terhadap al-Qur'an dapat kita temui dalam kehidupan sehari-hari, seperti cara mereka menghafal satu ayat al-Qur'an dan maknanya pada setiap pertemuan juga kebiasaan membaca surat yasin pada setiap malam Jum'at serta surat ar-Rahman dan Al-Waqiah pada setiap pagi.

Untuk lebih jelasnya, berikut disajikan data terkait pemahaman masyarakat kota Bandar Lampung terkait pengamalan studi Qur'an dalam kehidupan mereka sehari-hari. Data ini diambil dari 150 responden yang ditemui saat mereka melakukan pengajian di daerah setempat.

\begin{tabular}{|l|c|l|c|c|}
\hline No & $\begin{array}{c}\text { Ruang } \\
\text { Lingkup } \\
\text { Studi Al- } \\
\text { Qur'an }\end{array}$ & $\begin{array}{l}\text { Kecenderungan } \\
\text { Pemahamaan } \\
\text { terhadap Al- } \\
\text { Qur'an }\end{array}$ & $\begin{array}{c}\text { Jumlah } \\
\text { Jama'ah } \\
(150)\end{array}$ & $\begin{array}{c}\text { Persentase } \\
\text { (\%) }\end{array}$ \\
\hline 1 & $\begin{array}{l}\text { Diratasat Ma } \\
\text { Fi Al-nas }\end{array}$ & $\begin{array}{l}\text { Yang mempelajarai } \\
\text { Al-Qur'an hanya } \\
\text { dengan membaca } \\
\text { teks nya saja } \\
\text { secara benar sesuai } \\
\text { dengan tajwid dan } \\
\text { mengikuti } \\
\text { pengajian kajian } \\
\text { Al-Qur'an tentang } \\
\text { cara membaca dan } \\
\text { mengetahui } \\
\text { terjemahnya }\end{array}$ & $3,3 \%$ \\
& & & \\
\hline 2 & Dirasat Ma & Mengikuti kajian & \\
\hline
\end{tabular}




\begin{tabular}{|c|c|c|c|c|}
\hline & $\begin{array}{l}\text { Haula Al- } \\
\text { Qur'an }\end{array}$ & 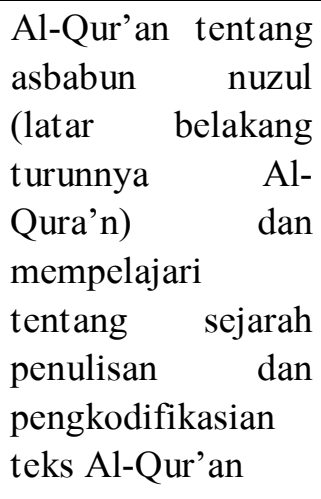 & & \\
\hline 3 & Kajian Tafsir & $\begin{array}{l}\text { Materi pengajian } \\
\text { seharusnya adalah } \\
\text { pemahaman } \\
\text { terhadap teks Al- } \\
\text { Qur'an dan Kajian } \\
\text { tematik dalam } \\
\text { studi Al-Qur'an } \\
\text { menjawab } \\
\text { permasalahan yang } \\
\text { ada dalam } \\
\text { masyarakat }\end{array}$ & $\begin{array}{c}40 \\
\text { Jama'ah }\end{array}$ & $26,7 \%$ \\
\hline 4 & $\begin{array}{l}\text { Kajian } \\
\text { Living } \\
\text { Qur'an Dan } \\
\text { Tafsir }\end{array}$ & $\begin{array}{l}\text { Menghafal satu } \\
\text { ayat Al-Qur'an dan } \\
\text { maknanya pada } \\
\text { setiap pertemuan } \\
\text { merupakan } \\
\text { kebiasaan pada } \\
\text { majelis taklim } \\
\text { kami dan } \\
\text { Narasumber dalam } \\
\text { pengajian } \\
\text { menganjurkan } \\
\text { jamaahnya untuk } \\
\text { membiasakan } \\
\text { membaca surat } \\
\text { yasin pada setiap } \\
\text { malam jumat dan } \\
\text { surat ar-Rahman }\end{array}$ & $\begin{array}{c}75 \\
\text { Jama'ah }\end{array}$ & $50 \%$ \\
\hline
\end{tabular}




\begin{tabular}{|l|l|l|l|l|}
\hline & $\begin{array}{l}\text { dan Al-Waqi'ah } \\
\text { pada setiap pagi }\end{array}$ & & \\
\hline
\end{tabular}

\section{F. Tren Studi Al-Qur'an Di Lingkungan Masyarakat Kota Bandar Lampung}

Salah satu tren atau kajian tentang studi Qur'an adalah dengan melakukan penelitian terhadap pemahaman suatu masyarakat tentang bagaimana cara mereka memposisikan dan memahami dan mempraktekkan setiap ajaran yang tertuang di dalam kitab suci al-Qur'an dalam kehidupan mereka sehari-hari. Untuk itu, setelah memetakan ruang lingkup studi Qur'an ke dalam empat kategori seperti yang telah dipaparkan sebelumnya, penelitian yang dilakukan di Kota Bandar Lampung ini pada akhirnya dapat ditarik sebuah kesimpulan tentang tren atau kecenderungan yang terjadi pada masyarakat kota Bandar Lampung. Kecenderungan atau tren tersebut antara lain dapat dilihat dari uraian berikut ini:

\section{Diratasat Ma Fi Al-nas}

Jika melihat bagan di atas, diketahui bahwa kecenderungan para jamaah pengajian kota Bandar Lampung yang mempelajarai al-Qur'an hanya dengan membaca teks nya saja secara benar sesuai dengan tajwid dan mengikuti pengajian kajian al-Qur'an tentang cara membaca dan mengetahui terjemahnya hanya sebanyak 30 jama'ah dari total 150 jama'ah yang menjadi responden pada penelitian ini. Itu artinya, ada sekitar $20 \%$ dari total jama'ah yang ada di sekitar kota Bandar Lampung. Jumlah ini terbilang relatif kecil mengingat ada banyak Taman Pendidikan al-Qur'an dan tempat-tempat les membaca al-Qur'an di kota Bandar Lampung ini sebagaimana yang telah dibahas sebelumnya.

Hasil ini tentunya sedikit mencengangkan karena seharusnya, sebagai umat Islam yang taat, membaca al-Qur'an itu sudah menjadi sebuah keharusan bagi setiap individu yang beragama Islam. Apalagi mereka telah dididik sejak kecil untuk belajar membaca al-Qur'an.

\section{Dirasat Ma Haula Al-Quran}


Jika Diratasat Ma Fi Al-nas pada masyarakat kota Bandar Lampung saja dikatakan cukup kecil, maka dalam bidang Dirasat Ma Haula Al-Qur'an yaitu mereka yang mengkaji al-Qur'an tentang asbabun nuzul (latar belakang turunnya al-Qur'an) sekaligus mempelajari mengenai sejarah penulisan dan pengkodifikasian teks al-Qur'an prosentasenya lebih kecil lagi. Bahkan dapat dikatakan yang terendah. Hal ini tampak dari jumlah jama'ah yang ada hanya sebanyak 5 orang saja yang melakukannya. Itu berati jika dipresentasekan, hanya sekitar 3,3\% dari total jama'ah yang ada.

Meski demikian, hal tersebut masing dianggap lumrah mengingat tidak semua orang yang dalam hal ini ada masyarakat muslim kota Bandar Lampung menguasai lebih dalam ilmu-ilmu seputar al-Qur'an yang di dalamnya mencakup ilmu al-Qur'an dan tafsir. Sebab, untuk sampai pada ilmu tersebut banyak hal yang harus dipelajari terlebih dahulu. Dan hanya mereka yang pernah atau sedang mengenyam pendidikan di Pondon Pesantren atau kuliah di jurusan keagamaan saja yang biasanya mengakaji alQur'an sampai sejauh itu.

Selain itu juga, kebanyakan dari masyarakat kita saat ini seringkali menghendaki segala sesuatunya bisa lebih berbentuk ataupun bersifat praktis dan instan. Artinya, mereka hanya akan melihat dari segi manfaat apa yang sekiranya mereka dapat dari menjalankan kegiatan tersebut.

\section{Kajian Tafsir}

Penafsiran atas ayat-ayat al-Qur'an adalah sebuah keniscayaan. Penafsiran ini muncul sebagai sebuah kegiatan untuk meresepsi al-Qur'an upaya mengaktualisasikannya dalam kehidupan sehari-hari sebagaimana yang diyakini sebagai pedoman hidup dalam mengarungi bahtera kehidupan di dunia. Bahtera kehidupan dunia yang penuh dengan gelombang permasalahan dan setiap permasalahan pasti membutuhkan pemecahan. Pencarian pemecahan inilah membutuhkan sinaran alQur'an, yang di dalamnya inheren dengan kegiatan penafsiran.

Penafsiran ini merupakan respon kreatif umat manusia upaya menghadapi kehidupan dan segala problematikanya dengan berbasis al-Qur'an adalah munculnya upaya-upaya untuk mengadaptasikan dan mengaktualisasikan ajaran-ajaran yang ada 
di dalamnya sesuai dengan dinamika dan akselerasi perubahan jaman. Tafsir seringkali disebut sebagai kunci pembuka kandungan al-Qur'an yang dianalogikan sebagai gudang yang menyimpan mutiara.

Karena itu, tidaklah mengherankan jika banyak juga masyarakat muslim yang tinggal di Kota Bandar Lampung menganggap bahwa materi pengajian seharusnya adalah pemahaman terhadap teks al-Qur'an. Karena dengan begitu, alQur'an yang secara normatif telah mengklaim dirinya sebagai kitab petunjuk ${ }^{9}$ haruslah mampu menjawab segala permasalahan hidup manusia. Sebab, sebagaimana yang telah diketahui bahwa kehidupan manusia di dunia pasti dipenuhi dengan permasalahan. Dari masa ke masa, permasalahan selalu berkembang menyesuaikan dengan tempat dan waktunya, hubungannya dengan yang lain, dan seterusnya.

Untuk itu, dengan mengkaji kandungan ayat-ayat alQur'an secara tematik diharapkan mampu menjawab permasalahan yang ada dalam masyarakat. Hal ini terbukti dengan melihat kecenderungan masyarakat kota Bandar Lampung point ini sebanyak 40 jama'ah. Jika diprosentasikan maka sebanyak $26,7 \%$. Jumlah ini tentunya lebih banyak dari jumlah jama'ah yang hanya mengkaji al-Qur'an dengan teks nya saja.

\section{Kajian Living Qur'an Dan Tafsir}

Dari keempat tren studi Qur'an yang menjadi pokok penelitian ini, tren living Qur'an dan tafsir menjadi yang paling banyak dipraktekkan atau digeluti oleh jama'ah muslim kota Bandar Lampung. Hal ini tampak dari jumlah jama'ah yang mencapai 75 orang dari total 150 koresponden yang menjadi objek penelitian ini. Jika diprosentasikan, maka jumlahnya mencapai $50 \%$. Itu artinya, separuh dari total jama'ah lebih cenderung untuk menghafal satu ayat al-Qur'an beserta maknanya pada setiap pertemuan dan selalu membiasakan membaca surat arRahman dan Al-Waqiah pada setiap pagi.

9 Tetapi secara historis justru sebenarnya manusialah yang membutuhkan al-Qur'an jika menginginkan kehidupannya berada pada jalan yang lurus (shirat al-mustaqim). 
Tidak hanya itu, karena juga bahkan membentuk kelompok-kelompok pengajian untuk melakukan pembacaan yasin dan tahlil pada setiap malam Jum'at secara rutin dengan bergiliran dari rumah ke rumah. Hal ini tentunya bukanlah hal yang aneh, sebab seperti kita ketahui bersama bahwa tradisi turun temurun yang dilakukan oleh mayoritas warna Nahdatul 'Ulama ini telah mendarah daging di kalangan jama'ah kota Bandar Lampung.

Dari uraian di atas, kita kemudian dapat memetakan bahwa tren studi Qur'an pada masyarakat kota Bandar Lampung lebih mengarah kepada tren kajian living Qur'an dan tafsir. Hal ini dapat dilihat dari hasil prosentase di atas, di mana tren kajian living Qur'an dan tafsir mencapai 50\%, disusul oleh tren kajian tafsir sebanyak 26,7\%, kemudian tren Diratasat Ma Fi Al-nas sebanyak 20\%, dan terakhir tren Dirasat Ma Haula Al-Quran sebanyak $3,3 \%$.

\section{G. Alternatif Studi Al-Qur'an pada Masyarakat Indonesia}

Alternatif Trend Studi Qur'an ini menawarkan pendekatan-pendekatan 'Barat' dalam memahami Qur'an, seperti pendekatan semiotika, tetapi tidak begitu saja lepas dari analisis Uhüm al-Qur'ān klasik. Pertanyaan lain yang muncul, apakah perkembangan studi Qur'an tersebut telah menyentuh 'posisi' Qur' an di tengah dinamika realitas kontemporer masyarakat Islam di Indonesia? Sepakat atau tidak, muslim di Indonesia sedang berada di muara jerat kapitalis medan produk-produk konsumerisme global. Diskursus Islam kemudian sulit dilepaskan dari tuntutan pasar; dengan kata lain masyarakat Islam dituntut untuk beradaptasi dengan pasar. Bagaimana studi Qur'an seharusnya menjawab realitas kontemporer yang lahir di Indonesia, seperti pengajaran tafsir di televisi atau model iqra, hafalan Qur'an atau pelurusan tajwid by phone di radio, layanan sms ayat, musabaqah tilawatil Qur'an atau puitisasi dan politisasi ayat, atau kaligrafi ayat yang begitu indah penuh simbol.

Perubahan zaman yang terjadi sekarang ini berdampak terhadap perkembangan teknologi yang semakin canggih dan memasuki hampir setiap aspek kehidupan manusia. Aspek kehidupan beragama pun tidak luput dari perkembangan teknologi. Hal ini pun menjadi tantangan tersendiri bagi kajian 
studi al-Qur'an pada masyarakat. Pengaruh perkembangan teknologi bagi penyebaran Islam, contohnya dapat dilihat pada aplikasi-aplikasi telepon genggam pintar (smartphone) yang dapat digunakan sebagai media beribadah, seperti aplikasi Qur'an dan pengingat adzan. Keberadaan aplikasi tersebut tentu sangat memudahkan manusia yang ingin senantiasa dekat dengan Allah SWT.

Begitupun dengan Tafsir yang mengalami perkembangan media dari sejak masa Nabi Muhammad saw. dengan tradisi oral, kemudian di era tulisan dengan tradisi penulisan kitab tafsir, era print yang ditandai dengan munculnya kitab dengan sistem print hingga saat ini dengan dimediasi oleh teknologi digital. Kemudian You Tube sebagai media baru yang mampu menjangkau batas ruang dan waktu yang tidak terbatas, mampu membangun sebuah komunitas virtual tak terbatas sebagai sebuah global village. Sistem penggunaan You Tube yang mudah dan dapat menjangkau berbagai objek tafsir dengan efektif menjadikan You Tube sebagai sebuah kepanjangan dari tradisi tafsir klasik yang mampu menghimpun tradisi tafsir klasik secara digital dan juga menjadi mufasir sebagai penyampai pesan al-Qur'an yang dapat hadir di muka audiens seolah tanpa batas ruang.

Persinggungan yang terjadi antara tafsir dengan teknologi digital ini berikutnya menyisakan berbagai dampak terutama ketergantungan masyarakat akan media digital dalam mengkonsumsi al-Qur'an, sehingga banyak kajian tafsir dilakukan secara virtual. Dari sini berikutnya muncul bentuk baru objek tafsir, baik digitalisasi objek lama maupun objek yang dengan bentuk baru seperti tafsir audio visual. Tafsir audio visual dalam hal ini muncul dengan klasifikasi baru yang belum pernah ada sebelumnya. Sebagai konsekwensinya objek baru ini berikutnya menuntut adanya perangkat analisa baru untuk mengkajinya. Pesinggungan ini pada akhirnya mengantarkan pada kemunculan Digital Qur'anic Studies sebagai pola kajian baru dalam diskursus studi al-Qur' an dan tafsir.

\section{H. Penutup}

Setelah memetakan ruang lingkup studi Qur'an ke dalam empat kategori; Diratasat Ma Fi Al-nas, Dirasat Ma Haula AlQuran, Kajian Tafsir, Kajian Living Quran Dan Tafsir. Maka 
dapat disimpulkan Bahwa trend studi Qur'an pada masyarakat kota Bandar Lampung lebih mengarah kepada tren kajian living Qur'an dan tafsir. Hal ini dapat dilihat dari hasil prosentase di atas, di mana tren kajian living Qur'an dan tafsir mencapai 50\%, disusul oleh tren kajian tafsir sebanyak 26,7\%, kemudian tren Diratasat Ma Fi Al-nas sebanyak 20\%, dan terakhir tren Dirasat Ma Haula Al-Quran sebanyak 3,3\%. Data ini diambil dari 150 responden yang ditemui saat mereka melakukan pengajian di daerah setempat. Sedangkan alternatif Trend Studi Qur'an dalam konteks kontemporer menawarkan kajian tafsir dengan kemunculan Digital Qur'anic Studies sebagai pola kajian baru dalam diskursus studi al-Qur'an dan tafsir. 


\section{DAFTAR PUSTAKA}

Abdul Mustaqim, Epistemologi Tafsir Kontemporer (Yogyakarta: LKiS, 2010).

(Yogyakarta : Pustaka Pelajar, 2008).

Abd Moqsith Ghazali (ed.), Metodologi Studi al-Qur'an (Jakarta: Gramedia, 2010).

Abuddin Nata, Metodologi Studi Islam, (Jakarta : Rajawali Press, 1998).

Rotroud Wielandt, "Tafsir al-Qur'an: Masa Awal Modern dan Kontemporer', dalam Tashwirul Afkar, No.18 tahun 2004. 